\title{
The Hiking Club: S.M. Abdullah and the Oettinger Women
}

Sheikh Muhammad Abdullah (1898-1956), also known as 'the Professor', went to Berlin in April 1928 to work as a missionary in the mosque. His education up to then had by no means been a religious one. ${ }^{1}$ As the son of a prosperous businessman from the Punjab, Abdullah pursued a modern academic career, which British colonial rule had made possible for him and his generation. After attending English-speaking schools, he studied physics and chemistry at Punjab University in Lahore, which culminated in a dissertation that was considered 'brilliant'. ${ }^{2}$ He viewed the position of a missionary as compatible with furthering his studies in Berlin. Far from being a religious scholar firmly anchored in Islamic tradition, Abdullah had worked in a highly abstract scientific discipline that operated with probability models and, in this respect, his profile was not unlike that of other Muslim reformers in the interwar period. ${ }^{3}$ From the viewpoint of the Berlin authorities, he was simply one of the many foreign students at that time who travelled to Berlin from all parts of the Muslim world to continue their studies. ${ }^{4}$

1 For short portraits of the four missionaries who worked in Berlin, see Gerdien Jonker, The Ahmadiyya Quest for Religious Progress: Missionizing Europe 1900-1965 (Leiden - Boston: Brill, 2016), 54-6o.

2 Anon, 'Obituary: Dr Shaikh Muhammad Abdullah', The Light, 35 (special issue, 26 August 1956), 2.

3 See, for example, Mehdi Sajid, Muslime im Zwischenkriegseuropa und die Dekonstruktion der Faszination vom Westen: Eine kritische Auseinandersetzung mit Sakib Arslans Artikeln in der ägyptischen Zeitschrift al-Fath, 1926-1935 (Bonn: EB-Verlag, 2015) 40-52, on the education of the Lebanese reformer Sakib Arslan.

4 Bekim Agai, Umar Ryad and Mehdi Sajid, 'Introduction: towards a trans-cultural history of Muslims in interwar Europe', in Bekim Agai et al. (eds) Muslims in Interwar Europe: A Transcultural Historical Perspective (Leiden - Boston: Brill, 2015) 1-18. On Arab students at German universities, see Gerhard Höpp, 'Zwischen Moschee und Demonstration: Muslime in Berlin, 1922-1930' (parts 1-3), Moslemische Revue, 3 (1990), 135-46; Moslemische Revue, 4 (1990), 2303; Moslemische Revue, 1 (1991), 12-9; Gerhard Höpp, 'Zwischen Universität und Straße: Ägyptische Studenten in Deutschland 1849-1945', in Konrad Schliephake and Ghazi Shanneik (eds) Die Beziehungen zwischen der Bundesrepublik Deutschland und der Republik Ägypten (Würzburg: Ergon Verlag, 2002), 31-42; Gerhard Höpp archive, 'Die Sache ist von immenser Wichtigkeit: Arabische Studenten in Berlin'; see Jonker, The Ahmadiyya Quest, 63-94. 
During his studies in Lahore, Abdullah had been a member of the Ahmadiyya Movement for the Propagation of Islam (Ahmadiyya Anjuman Ishaat we Islam Lahore). Founded in 1914 in Lahore, it was an upper-class Muslim reform movement that saw its mission as propagating a peaceful form of Islam that would work towards furthering the development of religion in a globalizing world. To achieve this, it adopted the Islamic tradition of greater jihad, the personal 'struggle of the heart.' ${ }^{5}$ Rather than taking political action, much less preaching violence, its members saw it as their duty to serve the advancement of the world by continually developing new fields of knowledge and furthering their studies. In this respect, they were not only thinking of themselves but also trying to change and improve their environment through proper action. ${ }^{6}$

The movement was considered controversial in the Muslim world. Its founder, Mirza Ghulam Ahmad (1834-1908) of Qadian in Northern India, originally aimed to wake up and release new energy to his co-believers living under British colonial rule. To this end, he proposed using reason rather than violence and seeking peaceful solutions. ${ }^{7} \mathrm{He}$ criticized the British missionaries' interpretations of Islam, grappled with Christianity, Hinduism and Baha'i, and tried to assemble criteria for a global religion. In this endeavour, he received encouragement from Muslim scholars, but when he suggested himself as the medium through which God would speak directly to the Muslims, they turned against him. His claim to the status of a minor prophet turned him into an object of bitter hatred. A group of supporters did form, but most Indian Muslims considered his attempt to give them a new self-awareness to be heretical, and he was severely condemned for it. ${ }^{8}$

After his death, his followers split into two camps. His supporters from Qadian, the village of his birth, did indeed view their founder as a new prophet of Islam, who consolidated the experiences of earlier prophets within himself and advanced them further. Because they also saw themselves as the only true Muslims, considering all others to be kafirs (non-believers), they intensified the conflict. ${ }^{9}$ Ahmad's students in Lahore, on the other hand, including Abdullah,

5 Rudolph Peters, 'Jihad', in John L. Esposito (ed.) The Oxford Encyclopedia of the Islamic World (Oxford: Oxford University Press, 2009), 252-6.

6 Muhammad Ali, who was their president from 1914 to 1951, theorized the notion of jihad as 'internal struggle', as practised by the Ahmadis of Lahore. See Muhammad Ali, 'Jihad', in Muhammad Ali, The Religion of Islam (Columbus, Ohio: AAII, 1990), 405-43.

7 Mirza Ghulam Ahmad, 'A proposal for the utter extinction of jehad', The Review of Religions, 2 (1) (Qadian, 1903) 20-9.

8 Jonker, The Ahmadiyya Quest, 12-36.

9 Jonker, The Ahmadiyya Quest, 36-63. Today the followers from Qadian call themselves $A$ madiyya Muslim Jamaat and they constitute the largest successor organization worldwide. 
condemned such radical views. The newfound Lahore-Ahmadiyya presented itself as cosmopolitan, open to the modern world, and liberal. It hoped to renew the Muslim world through engaging in scientific discourse with European thinkers. From its founder it adopted only those aspects that had already found acceptance within Sunni Islam.

The Lahore-Ahmadiyya mission was rooted in the conviction that it should not be left up to the British to determine what Europeans thought about Islam. Instead, Muslims should themselves become active and try to engage in discussions with European elites. To this end, the organization attempted to found missions throughout Europe. ${ }^{10}$ Its missionaries built a mosque in Berlin in 1924. They also succeeded in persuading a considerable number of Germans to convert to Islam. ${ }^{11}$ Thanks to their success in Europe, for quite a while the intellectuals from Lahore enjoyed a good reputation among Muslim reformers. However, the relationship remained ambivalent because of constant agitation from their brother organization in Qadian. ${ }^{12}$

In 1921, Abdullah married Sakina Begum, the daughter of a zamindar, an important aristocratic landowner who could trace his genealogy back to the Mughal era. ${ }^{13}$ The following year, Abdullah was appointed lecturer of physics at Islamia College in Lahore and his future seemed assured. A photograph from this period still hangs in the mission house next door to the Berlin mosque. It shows him alongside his college hockey team, with the British school director beside him, and around him the hockey players with their muscular legs. He himself looks impeccable in a European suit and, as a testament to his position in the landowning class, a turban with the tip pointing upwards is wrapped around his head.

However, Sakina's unexpected death interrupted his career. Abdullah's second wife Mahmuda, a niece of Sakina Begum, remembered in 1956 that at first Abdullah was so disoriented that he vowed never to marry again and to devote

10 Nathalie Clayer, 'Behind the veil: the reform of Islam in interwar Albania or the search for a "modern" and "European" Islam', in Nathalie Clayer and Eric Germain (eds) Islam and Inter-War Europe (New York: Columbia University Press, 2008) 128-56; Eric Germain, "The first Muslim missions on a European scale: Ahmadi-Lahore networks in the inter-war period', in Nathalie Clayer and Eric Germain (eds) Islam and Inter-War Europe (New York: Columbia University Press, 2008), 89-128; Jonker, The Ahmadiyya Quest, 36-63.

11 Jonker, The Ahmadiyya Quest, 63-94.

12 Umar Ryad, 'Salafiyya, Ahmadiyya, and European converts to Islam', in Bekim Agai, Umar Ryad and Mehdi Sajid (eds) Muslims in Interwar Europe: A Transcultural Historical Perspective (Leiden - Boston: Brill, 2015) 47-88.

13 Anon, 'Obituary', 3. 
his life entirely to Islam. ${ }^{14}$ And so it happened, although after that everything progressed very differently from what might have been predicted in Lahore.

At the time Abdullah took his vows, the Lahore-Ahmadiyya was looking for a suitable candidate to succeed the missionary in residence in Berlin. Being young, single, diplomatic, with a sharp mind and a talent for organizing, he was selected. We can assume that Abdullah was not averse to leaving his hometown for a while, for he arrived in the German capital as a student in April 1928 to do what all new foreign students did. He registered at Berlin University with a view to embarking on another doctorate but ended up on one of the many German language courses that the university required as a prerequisite for studying in Germany; he also looked around for a private tutor.

He first encountered Emilia Oettinger and her daughters Lisa and Susanna in their private home; three photographs survive that meeting (Figure 3.1). Although still at school, Susanna was giving English lessons to boost the family's income and Abdullah soon became one of her students. In one photograph, he is sitting between the two young women on an art nouveau sofa with a bashful smile on his face. Susanna's hands are tightly folded on her lap and she is looking up at him in awe. In a second photograph he is sitting on a stool at the piano, with the awkward turn of his body suggesting insecurity. In the third picture, which must have been taken later the same year, the sisters are wearing white summer clothing and Lisa has her arm around his shoulder. Yet, the three seem rather anxious. The pictures capture not only their embarrassment and distance from one another, but also a certain curiosity about the unknown and foreign, which had obviously overcome them all. 'Ritterstrasse 91' is written in Emilia's handwriting on the back of the photos, which form part of a collection of about fifty snapshots that Emilia had collected from Abdullah and his Islamic congregation in Berlin between 1928 and 1939. She labelled them with dates, names and places and, in pictures, they tell the story of the impact of the encounter and the friendships that developed..$^{15}$

\section{1 \\ Islam in Berlin during the Weimar Republic}

The secret of Abdullah's success in Berlin lay in his genteel manner, his practical suggestions for coping with everyday life, and the smoothness with which he could adapt to the different trains of though in his congregation and steer them towards an Islamic interpretation. During his time as imam, the topics

\footnotetext{
14 Mahmuda Abdullah, 'My loving husband', in Anon, 'Obituary', 6-7.

15 Private Oettinger family archive.
} 

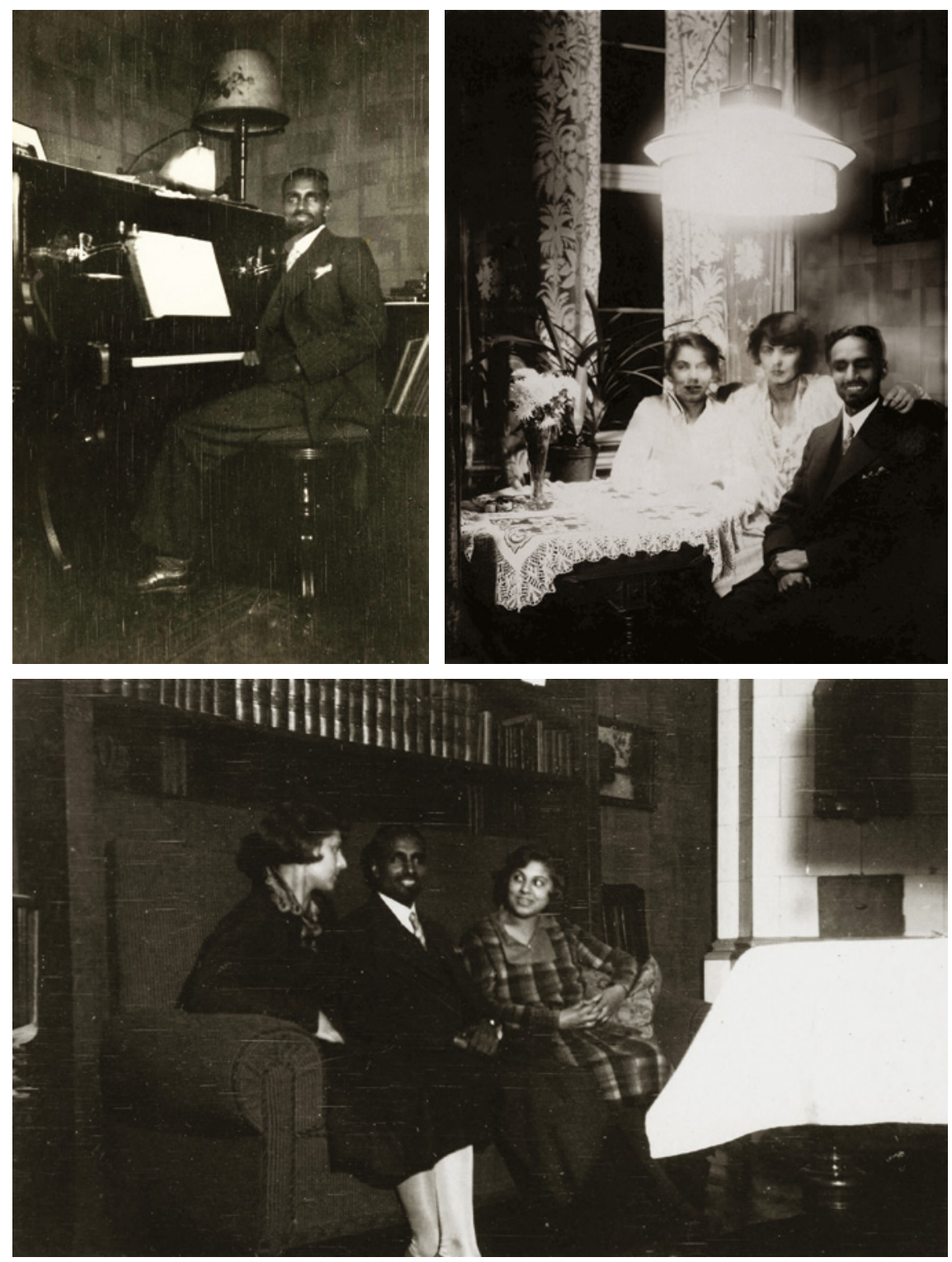

FIGURE 3.1 (3 photographs). S.M. Abdullah's first visit to the Oettinger home, 1928

covered at the monthly evening lectures tended to veer away from the great theories or the minefield of dogmatics, and they certainly steered clear of contemporary political themes. Instead, he and the numerous Indian and German speakers who were invited to lecture in the mosque spoke of Mohammad as a model for a simple lifestyle, of the relationship between the Quran and daily 
prayer, of the Muslim way of life, which fitted well with the German life reform movement (Lebensreform), of the women whom the Prophet wanted to emancipate, and of one's own soul as a place of understanding. ${ }^{16}$ These were themes that impressed his Berlin audiences, who belonged to the bourgeois elite, which the First World War and the chaos that followed during the Weimar Republic, had devastated. Often, they had lost all their capital and were now seeking routes to redemption. Many had experimented with Theosophy before joining the mosque community.

The lectures had been discontinued for some time before Abdullah arrived. The previous missionary had been a poor organizer and, when he went, he left utter chaos behind him. It took until late in the autumn before Abdullah got everything in order and, in October 1928, he was finally ready. Hugo Marcus, who organized the mosque lectures and had been editing the mosque's quarterly publication, the Moslemische Revue, since 1923, introduced him to its readers by saying, 'Mr Abdullah has been a university professor in Lahore. He gave up a large sphere of activity to assume the missionary post here.'. ${ }^{17}$ That set the tone. As young as he was, Abdullah knew how to consolidate his authority and this earned him the epithet 'the Professor', which stayed with him all his life. No one seemed ever to address him by his first name, not even the Oettinger women, who by this time had already adopted him as a family friend.

The Oettingers' relationship with Abdullah opened unimagined possibilities. Emilia Oettinger threw herself and her daughters into life around the mosque, but it was she, the mother, who set the course. As we shall see in the next chapter, her daugthters were still very young in 1928, Lisa 20 and Susanna 18, so they did not begin to add their own personal touches to the events until 1932. In the group photographs taken in front of the mosque at the end of Ramadan in March 1929 and at Eid al-Adha the following May, they were already very involved. ${ }^{18}$ The corresponding pictures in Emilia's collection have inscriptions: 'FRAU OETTINGER, A HUMBLE PRESENT AS A TOKEN OF HEARTY GRATIFICATION FOR THE PLEASANT COMPANY DURING THE CELEBRATION OF EID AL-FITR ON 12 MARCH 1929, MUMTAZ' She does not tell

16 This conclusion is based on my evaluation of the Moslemische Revue (1930-40). The 88 main articles, almost all of which were based on earlier lectures, treat the following themes: the life of the Prophet (7); the Quran and prayer (19); the soul, mysticism, Aryans, and the East-West encounter (20); a Muslim way of life and German life reform (12); Sharia and gender relations (14); and the history of Islam (14). Not until 1939-40, under the cloud of the Second World War, were there also some political contributions (2).

17 Anon, 'Unsere Versammlungen', Moslemische Revue, 1 (1929), 2-3.

18 Moslemische Revue, 2 (1929), 1; Moslemische Revue, 3 (1929), 1; and Moslemische Revue, 1 (1930), 1. 
us who Mumtaz was or what happened to him subsequently. The large quantity of photographs with inscriptions does, however, demonstrate that a new circle of friends quickly developed. The same Mumtaz gave Susanna a picture of himself with the somewhat clumsy inscription: 'TO MY SUSCHEN. MUMTAZ, EID EL-FITR, 15 MARCH 1929'. It was in fact Susanna who was surrounded by admirers, including a certain Munsi and the missionary Majid, who wrote the following on his passport photograph: 'SUSE. IN REMEMBRANCE ALWAYS. BERLIN, 4 DECEMBER 1929'.

The collection includes pictures of Mumtaz, Munsi, Majid, Abdullah (with and without inscriptions), and of unidentified women and men. They show the two sisters somewhat awkwardly wrapped in saris in the company of aristocratic Indian men and refined Indian ladies, and at large parties with long tables set for the end of the day of fasting. They also feature the initiative that their mother introduced to the congregation in spring 1929, namely walking tours of Berlin, which became a fixed part of mosque life, at least until it all finally fell apart in 1939 .

Hiking was an integral part of the German life reform movement and Emilia Oettinger was a veritable hiker. When she introduced her passion to the congregants of the Ahmadiyya mosque, she received positive feedback. Although the Indians did not share precisely the same ideas about reform, which involved physical exercise, love of nature, and sunbathing, theirs were similar. Abdullah, who had grown up in the culture of British colleges, was an athlete and had led the hockey team at his college in Lahore. A hiking group was formed and, before long, the new friends were putting on their walking shoes and taking off for entire days. While hiking, they got to know each other and sometimes went to restaurants together. Soon, however, outdoor picnics became a popular pursuit. The first hike, which was 'from Rehbrücke to Templin', was also the most ambitious. It started almost 20 miles south of Berlin, led right through the city, and ended five days and 80 miles later in beautiful Templin in Brandenburg. The 'tour to Kienitz Lake' was also a rather long hike that led from the centre of Berlin to about 50 miles into the Oderbruch marshes. In the autumn of 1929, the distances covered became shorter and settled at under 20 miles. Berlin was surrounded by nature and one did not have to go far to get there. Forests, lakes and meadows provide constant backdrops to the photographs of the numerous hikes to the Kalkberg (limestone mountain) in Rüdersdorf, the Sacrow Lake near Potsdam, and the Hellsee Lake north of Bernau. Hanging in the Oettinger's dining room were colour photographs of all the larger lakes around Berlin. ${ }^{19}$ Emilia's photograph collection included stacks of

19 Found in Lisa Oettinger's chests. Private Oettinger archive. See Chapter 4. 
the same views, but with the decisive difference that they were populated by Indians.

Apart from the three Oettinger women, 'the Professor' is the only person to appear in every single photograph. From 1932 onwards, when Azeez UrRahman Mirza became assistant imam, he was also part of the hiking group. After a visit to Lahore in 1933, Abdullah returned with his new wife Mahmuda, and she too joined the group. There are also other Indian faces on the photographs that can no longer be identified. The group appears to have included a total of eight to ten people. Neither ice, snow, rain nor sweltering heat kept them from taking their hikes. With a hat and coat in winter and a throwing stick in summer, they continued to hike all over Brandenburg under Emilia's leadership for a good ten years. Over this time, close friendships developed that remained intact throughout their lives.

Life reform got the mosque moving. Emilia's cheerful face appears in the group photographs at the tennis court ('our corner in Grunewald forest'), during her frequent sunbathing breaks in the mosque garden, and at rowing parties and sailing trips on the Wannsee Lake. Physical activities and a love of nature soon provided a casual setting in which young people could socialize and romances easily blossom. The German physical culture movement, which had almost a million registered members in the Weimar Republic, viewed the 'body as a sacred space, and its care as a sacred act'. ${ }^{20}$ Feeling one with nature was also a fixed aspect of the German way of giving meaning to life and spirituality. That Emilia and her daughters combined Islam with life reform shows that they too sensed a certain spirituality in their experiences with their bodies and with nature.

The Indian side, however, saw physical activity more as a concession to modernity. ${ }^{21}$ For Abdullah, this was about 'polishing' body and spirit, and thus refining them. For his missionary work to be successful, he had to adapt to his congregation and learn everything he could about it. At the heart of his mission, though, was the need to convey the Muslim tradition in a form that was accessible to Christian and Jewish Europeans. In the monthly lectures, he sometimes strayed from the main themes to encourage his congregants to seek common ground between Indians, Germans, Muslims and secular Europeans. In the Moslemische Revue articles, this common ground was neither 'Eastern'

$20 \quad$ Bernd Wedemeyer-Kolwe, Der neue Mensch: Körperkultur im Kaiserreich und in der Weimarer Republik (Würzburg: Verlag Königshausen \& Neumann, 2004) quotation on p. 24, statistic on p. 425 .

21 C.A. Bayly, The Birth of the Modern World 1780-1914 (London: Blackwell, 2004), 12-9 et passim. 
nor 'Western', but a space in between the two, albeit a space that had yet to be found. When Abdullah assumed his post, it was still uncertain where such a space might lie - in thought, action, emotion, or perhaps all three? In this search, the central Muslim themes - coping with everyday life, finding a new order of gender relations, and understanding the soul - took on both a theoretical and a practical face. A form of interculturality was developing in the mosque, being pondered out loud and experimented with in everyday life.

\section{The Founding of the German-Muslim Society}

Two years after Abdullah arrived in Berlin, the search for common ground assumed its own organizational structure and, on 22 March, the German-Muslim Society was founded and its charter submitted to the district court. ${ }^{22}$ According to the statutes, the future society would bring together Muslims and nonMuslims who wanted to work for the greater social acceptance of Islam. As suitable means to achieve this goal, the founders suggested 'outreach work, lectures, and intensive congregational life.'. ${ }^{23}$ Muslims and non-Muslims could join the society, with the latter divided into those 'who accept the goals and purposes of the Society' and those 'who sympathize with them'. ${ }^{24}$ Whether Muslim, supporter, or sympathizer, all members had the same voting rights. Initially, only Muslims could run the organization. To correct this asymmetry, however, two non-Muslims were invited to sit on the executive board.

Emilia Oettinger declared her willingness as a non-Muslim to sit on the board. It is impossible to determine to what extent she helped to write the bylaws. In any case, one can imagine that the subject was discussed on many a hike. The minutes of the board's first meeting contain the names of the seven executive members, including Emilia. The official photograph taken on the day the society was founded shows all of them (Figure 3.2$).{ }^{25}$ It is apparent from the composition of the executive board that the forces that came together in the society were very varied, which a short presentation of the dramatis personae illustrates.

Hugo Marcus (1880-1964), the philosopher who was chairman of the board until 1935, is sitting in the middle. Like Emilia Oettinger, Marcus was a life

\footnotetext{
22 Registry Office Berlin-Charlottenburg, No. 8769, 'Satzungen', 1. See Moslemische Revue, 2 (1930) 53-4.

23 Ibid.

24 Ibid.

25 Registry Office Berlin-Charlottenburg, No. 8769, 'Report' No. 1, 2.
} 


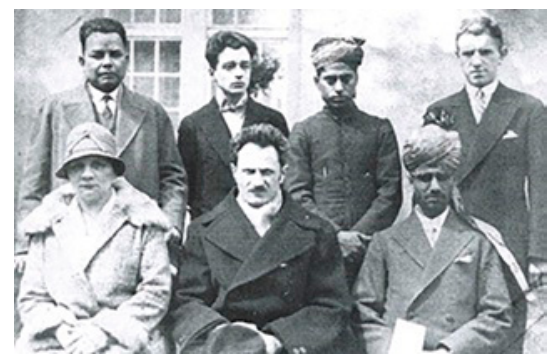

FIGURE 3.2

The founding board of the German-Muslim Society, 1930

reformer and, like her, had hiked as a youth and raved about German nature. ${ }^{26}$ However, whereas the Oettinger family was at the centre of the mosque's community life and very visible in the photographs, Marcus was a secretive person who kept to his own male circle and was barely visible. As I shall explain in Chapter 5 , the missionaries allowed him a wholly different form of male bonding, one in which he found acceptance for just who he was. There was little apart from their unwanted Jewish heritage that he and the Oettinger women shared. However, whereas the Oettinger family already had a history of having left the faith, Marcus was the first in his family to leave Judaism and it must have thus been difficult for him. Although he considered himself a Muslim as early as 1925, it was not until May 1936 that he decided to withdraw officially from the Jewish community. ${ }^{27}$

To his right is 'Professor S.M. Abdullah, secretary general', wearing the head covering that in Berlin was considered a sign of his position. To his left is Emilia Oettinger, the 'non-Muslim member', who at 54 was the oldest on the executive board. These three formed the core of the German-Muslim Society in 1930. The division of labour was clear. While Marcus held the lectures and Emilia coordinated the 'intensive congregational life', Abdullah was in charge of 'outreach' and of holding the reins.

Standing behind these three are the four people who were to integrate the four most important interest groups into the mosque community. On the far left is Dr A. Mansur, an Egyptian doctor who represented the Egyptian Muslims in the mosque. These were the Egyptian circus artists, restaurant owners and jazz musicians from around the Kurfürstendamm, who led a secular life and came to the mosque only to get married and to break their fast. ${ }^{28}$ After the Nazi takeover they would be joined by the Sufi community of Inayat Khan and its

26 For the story of his conversion, see Jonker, The Ahmadiyya Quest, 144-5.

27 The Centrum Judaicum Berlin archive contains a card certifying his having left the Jewish community, no. 10D9o, on 18 May 1936; Hugo Marcus private archive, box 1, certificate of conversion to Islam on 30 November 1932. 
charismatic Sufi master, the Persian Hossein Kazemzadeh Iranschär (see below). The more politically active Arabs in Berlin tended to avoid the mosque.

Standing next to Dr Mansur is a certain G. von Gutzkow, the representative of a relatively large group of Prussian aristocrats and former military officers. Not much is known about him, but evidence of the commitment of former officers to Islam can be found throughout the issues of the Moslemische Revue. They are testimony to the profound shock the men endured on the battlefields of Europe, combined with positive experiences with Muslim communities in North Africa. The Prussian aristocracy formed its own group in the GermanMuslim Society, which displayed a military interest in Islam from a perspective that would last through from the First to the Second World War. ${ }^{29}$

To the right of Gutzkow is M.T. Ahmad, the treasurer. At that time Ahmad was still a medical student at Berlin University. His head covering indicates that he belonged to the Indian landowning class. His contributions to the Moslemische Revue mark him out as a conservative thinker. ${ }^{30}$ More than twentyfive years later he would write a reference in Lahore for Hugo Marcus, who at the time was fighting for restitution; Ahmad wrote that it was Marcus who taught him German, introduced him to German culture and society, and edited his scientific articles written in German. ${ }^{31}$ While the Oettingers and Abdullahs were connected through friendship, so too were Marcus and Ahmad, and this must have gone a long way towards ensuring the smooth functioning of the executive board.

Werner Omar Schubert is on the far right of the photograph. The minutes of the meeting record that he is a Muslim and the deputy auxiliary secretary. Schubert had also joined the Nazi Party prior to 1930 and, without explicitly wanting to become politically active, he represented the people in the German-Muslim Society who supported Nazism. This group was interested in the affinity between so-called Nordic culture and Islam, which was introduced into the discussion by travellers to the Orient such as Else MarquardsenKamphövener and university professors R.H. Grützenmacher, GotthardJäschke, Ernst Kühnel, Hans-Heinrich Schaeder, and others. ${ }^{32}$ In his contributions

29 Jonker, The Ahmadiyya Quest, biographies on pp. 36-63; military interest in Islam on pp. 182-212.

3o Moslemische Revue, 1 (1993), 46-7; Moslemische Revue, 2 (1933), 69-84.

31 Private archive of Hugo Marcus, box 1, certificates and expert reports.

32 A comparison of the lists of lectures in the mosque archive and the articles in the Moslemische Revue shows that not all the transcripts of the speeches were published. For example, Else Marquardsen-Kamphövener gave a strongly anti-Jewish lecture in 1936 titled 'Leben und Sendung des Propheten Muhammad' ('Life and Mission of the Prophet Muhammad'), which she was unable to publish until 1941 in Die Auslese. See Ahmadiyya Mosque archive, no. 38; Ludmilla Hanisch, 'Akzentverschiebung: Zur Geschichte der 
to the Moslemische Revue, Schubert accorded himself the title of Sheikh, which gave him a certain authority commensurate with his experience with Islam in the Islamic world. ${ }^{33} \mathrm{He}$ too remained in office until 1935. He then changed sides, along with others in the German-Muslim Society such as Fischer, Konieczny, Beyer, Seiler, Hiller, and Klopp von Hofe, who were '10o per cent' committed to the Nazi Party, and joined the Muslims in the Berlin Islamic Community, which at that time were leading a worldwide campaign against the Ahmadiyya. ${ }^{34}$ For the German-Muslim Society this represented a turning point, which will be discussed in greater detail later.

There was no representation in the German-Muslim Society specifically for Jews, but it would also not have been in their interest. Like the Oettingers, members of the Hermann (architect K.A. Hermann had built the mosque in 1924), Weiser and Barthelemes families (to name just a few) were seeking ways of leaving Judaism behind them. In their eyes, the German-Jewish synthesis, for which their families had fought for generations, did not suffice. ${ }^{35}$ Some came from secularized Jewish families, others had previously converted through baptism, ${ }^{36}$ but most had experimented in some form or another with life reform and Theosophy prior to engaging with Islam.

The number of baptized Jews in Berlin was particularly high ${ }^{37}$ and, in the whole of Germany in 1924, there were 35,000 mixed marriages, in which the

Semitistik und Islamwissenschaft während des dritten Reichs', Berichte zur Wissenschaftsgeschichte, 18 (1995), 217-26; Jonker, The Ahmadiyya Quest, 192-9; David Motadel, 'Berlin's Muslim Moment', in David Motadel, Islam and Nazi Germany's War (Cambridge: Belknap Press of Harvard University Press, 2014), 38-71.

33 Moslemische Revue, 1 (1931), 39-47; Moslemische Revue, 1 (1932), 17-26.

34 Ryad, 'Salafiyya, Ahmadiyya', 80-1.

35 The most important representatives of German Jews approved of the German-Jewish synthesis; their members were largely secularized. See Avraham Barkai, 'Wehr dich!' Der Centralverein deutscher Staatsbürger jüdischen Glaubens (C.V.) 1893-1938 (Beck: Munich, 2002), 3 et passim.

36 The private archives of the Oettinger family and Hugo Marcus provided information on this, as did conversations with descendants of the Oettinger and Hermann families. Additional information came from the written correspondence between the Gestapo and the German Foreign Office. Abdullah's adversary Habibur Rahman also mentioned some names (AA PA 104.801, August to November 1939).

37 A committee of the Protestant Church in Berlin-Brandenburg traced the Protestant baptized Jews who belonged to their congregations in the period 1850-1940. In the 12 districts examined, the number tended to be rather high - for example, the St Marien and St Nikolai congregations in Berlin-Mitte (451 members); the Sophien church in Berlin-Mitte (344 members); Wilmersdorf (350 members); Grunewald (300 members), and Lichterfelde (147 members). Hildegard Frisius et al., Evangelisch getauft - als Juden verfolgt: Spurensuche Berliner Kirchengemeinden (Berlin: Working Group on Christians of Jewish Descent during the Nazi era in the Protestant Church, 2008), 30-1, 74 n2, 224, 261, et passim. 
Jewish partner remained a member of the Jewish community. The number of men of Jewish heritage who were baptized and married to Christian women is unclear. ${ }^{38}$ The number of children from mixed marriages was estimated to be 112,000 in $1935 .{ }^{39}$ Part of this group had already explored religious alternatives within the framework of the life reform movement. The many different missions that were established in Germany after the First World War offered a unique opportunity to do this. ${ }^{40}$ Those who ended up in the proximity of the mosque came into contact with an innovative force that was permeating German culture. As explained in Chapter 2, the Ahmadiyya mission was by no means the only one around. There were also the Berlin Islamic Community, the Inayat Khan Sufi Lodge, the Buddhist House, and the many Theosophical lodges that offered alternative visions in which a synthesis between Europe and the Orient was worked out. The Jews were among the most active members of most missions. ${ }^{41}$

38 Beate Meyer, 'Mischehe' und 'Mischlinge', in http://www.swr.de/swr2/ stolpersteine/ themen/mischehe (13 July 2016); Kerstin Meyring, Die Christlich-Jüdische Mischehe in Deutschland 1840-1933 (Hamburg: Dölling und Galitz Verlag, 1998), 92.

39 Saul Friedländer, Nazi Germany and the Jews, 2 vols., vol. 1: The Years of Persecution 19331939 (London: Weidenfeld \& Nicolson, 1997), 150-1; James F. Tent, In the Shadow of the Holocaust (Lawrence, KS: University Press of Kansas, 2003), 2.

40 No summary exists. For entries on Buddhists, German Faith Movement groups, anthroposophists, and non-denominationists (Freireligiöse) see Diethart Kerbs and Jügen Reulecke (eds) Handbuch der deutschen Reformbewegungen (Wuppertal: Hammer Verlag), 495-611. For remarks on religion and life reform see Kai Buchholz, Rita Latocha, Hilke Peckmann, Hilke Wolbert and Klaus Wolbert (eds) Die Lebensreform: Entwürfe der Neugestaltung von Leben und Kunst um 1900 (Darmstadt: Häusser-media, 2001), 187-211. On the School of Wisdom in Darmstadt, see Suzanne L. Marchand, 'Eastern wisdom in an era of Western despair: Orientalism in 1920s central Europe', in Peter E. Gordon et al. (eds) Weimar Thought: A Contested Legacy (Princeton: Princeton University Press, 2013), 341-6o.

41 With respect to the Berlin Islamic Community, much has been written on Leopold Weiss and Lev Nussimbaum. For an overview of the literature and a summary of the (conversion) biographies, see Jonker, The Ahmadiyya Quest, $133-45$. With respect to the Sufi movement, after the Nazis came to power, the Inayat Khan Sufi Lodge disbanded and wrote to the registry office that 'the Sufi movement as such no longer exists, because ... as an international movement it entitles Jews to equal rights', Registry Office Berlin-Charlottenburg, No. 94 VR 4635 (1 November 1933). On the Buddhists, see Sebastian Musch,Jewish Responses to Buddhism in German Culture, 1890-1940 (London: Routledge, forthcoming 2019). With an eye to the Buddhist House in Berlin-Frohnau, Martin Baumann, "Importierte" Religionen: Das Beispiel Buddhismus', in Diethart Kerbs and Jürgen Reulecke (eds) Handbuch der deutschen Reformbewegungen (Wuppertal: Hammer Verlag, 1998), 518 noted that 'the share of early Buddhists who had been Jews was remarkably high relative to the population (roughly one-third)'. 


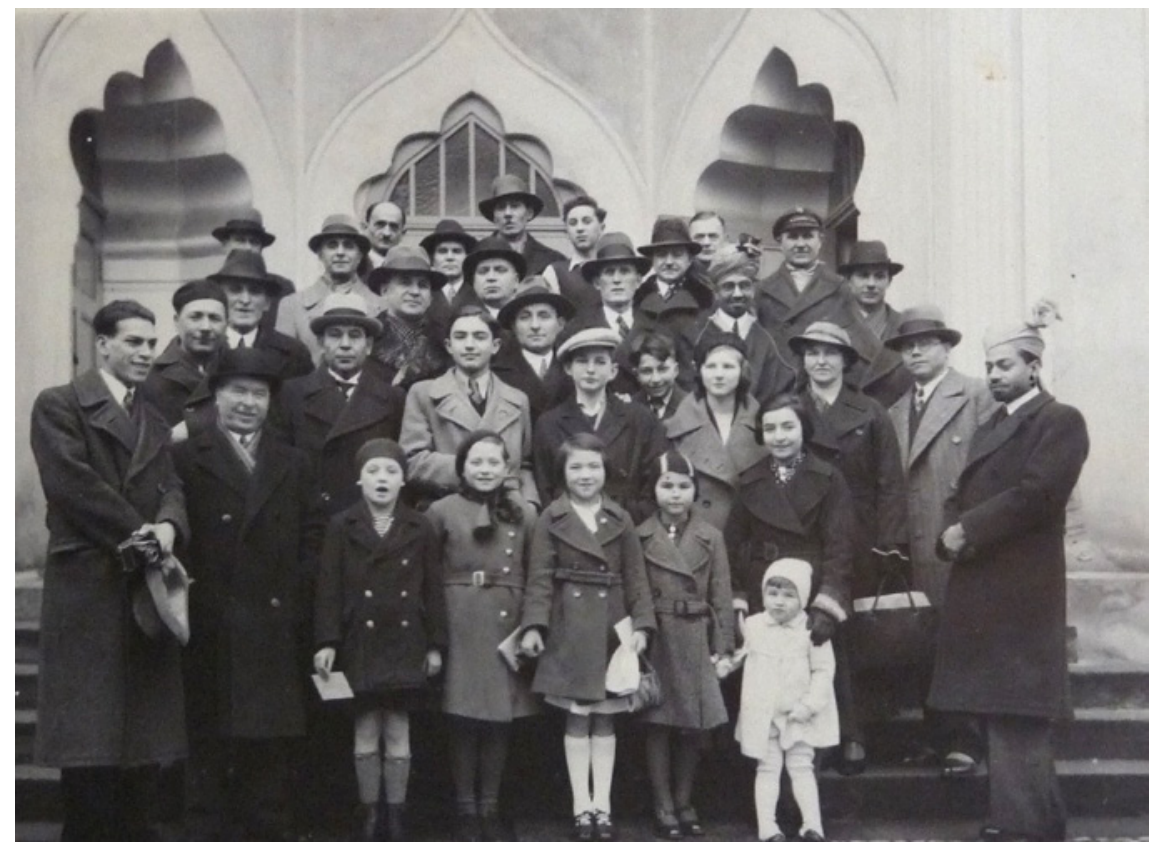

FIGURE 3.3 The Ahmadiyya community, c.1935

In sum, in 1930 S.M. Abdullah held together an extremely heterogeneous society that brought together not only Indians, Tatars, Arabs, Persians, Germans, Ahmadiyya Muslims, orthodox Sunni, Shi'a and non-Muslims, but also secular Christians, Jews, liberals, conservatives and Nazis. Although the GermanMuslim Society was expressly non-political, the political differences were at this time already becoming apparent. In the group photograph taken at the Eid al-Fitr celebration in 1935, everyone can be seen together (Figure 3.3). According to Abdullah, at this time the congregation already contained around 100 converts and 400 'friends of Islam. ${ }^{42}$

Emilia's eldest daughter Lisa became a Muslim in 1933. Emilia herself remained among the 'friends' and did not convert until 1947. Yet, whatever form of affiliation they chose, the mosque was their life from then on. It was where they talked, hiked, played tennis, had 'wild' romances and gave birth to children. Their friendship with Abdullah was their compass. For the Oettinger women, the central themes discussed in the mosque, such as new ways of living, gender relations and the nature of the human soul, had practical consequences. From 1930 onwards, discussions on the 'new men and women' who

42 Registry Office Berlin-Charlottenburg, No. 8769/annual report 1931. 
would unite Europe and Islam, kept the congregation in suspense and left a deep impression on the lives of Lisa and Susanna. In the next section, we shall go into this in greater detail.

\section{New Men and New women}

There were many visions of the 'New Man' being bandied about in Germany before the Second World War. All the major political movements, as well as the art scene, the life reform and the physical culture movements, were interested in fashioning a human being of the future who would be capable of mastering the challenges of the new age. To this end, communist Russia was paying homage to the notion of a 'common, grounded' human being who, in the daily struggle for survival had learned to shoulder both the constant and the changeable and to create a balance between them. In the words of the literary critic Alexandr Voronsky in 1923, 'in the lazy, fat-assed "Oblomov" Russia, a new human race appeared - simple and strong as nails. 43

As strong as nails is what the Nazis also wanted to be. They wanted their youth to be as 'swift as a greyhound, as tough as leather, and as hard as Krupp's steel', or so Hitler told them in the Nuremberg stadium in $1935 .^{44}$ Realizing that such an ideal was a huge undertaking, in an elite training centre called Ordensburg, young boys were turned into 'living tools of the Führer', prepared 'to prove their manliness, their courage, their determination and audacity at any time. ${ }^{45}$ In other words, they were being used in the war as cannon fodder to be sacrificed for the Nazis' goals.

Members of the life reform and physical culture movements believed in individual self-reform. In Der neue Mensch, Bernd Wedemeyer-Kolwe describes the infinite range of body practices with which people could start 'working' on themselves. These include rhythmic dancing, gymnastics, yoga, Mazdaznan, meditation, Rune exercises, hiking, open-air swimming, nudism, home training, bodybuilding and muscle competitions. Artists like Fidus (Hugo Höppener) raved about 'strength through beauty' and painted muscular, nude bodies. ${ }^{46}$ His followers revered him as a 'sacred temple' with a 'sacred duty' to

43 Cited in Andrei Sinyavsky, Soviet Civilization: A Cultural History, translated by Joanne Turnbull (New York: Arcade, 1990), 45.

44 https://www.dw.com/en/hitlers-odd-appeal-to-german-youth/a-16410476.

45 Franz Albert Heinen, Ordensburg Vogelsang: The History of the NS-Elite Training Centre in the Eifel, translated by Laura McLardy (Berlin: Ch. Links Verlag, 2014), 53.

46 Janos Frécot, Johann Friedrich Geist and Diethart Krebs, Fidus 1868-1948: Zur ästhetischen Praxis bürgerlicher Fluchtbewegungen (Berlin: Rogner \& Bernhard, 1997), illustration sec- 
eradicate the 'severe social upheavals that we and the entire world are going through' by returning to 'primal healthy conditions'. If this were performed well, then the pressing problems of the day would be solved, as if by magic. ${ }^{47}$

Against this background, it is hardly surprising that the members of the life reform (Lebensreform) movement within the German-Muslim Society - and they were in the majority - should want to produce their own draft. By bundling together various forces in the society, their model considered someone who broke away from Europe to merge with the Orient as a 'true European'. It was only in 1936, when pressure from the secret police became unbearable and members were leaving in droves, that the creative energy expended on shaping such a 'New Man' also waned.

Hugo Marcus, the German-Muslim Society's thinker, made a start in 1930 with a discussion in the Moslemische Revue. ${ }^{48}$ He stated that 'we have to create new human beings because we ourselves are responsible for heaven and hell'. ${ }^{4}$ With that, he made it clear that he was interested in neither making the common man a hero nor in exalting youth. It was close to his heart to create human beings who accepted responsibility for themselves by seeking the divine within their soul. The proper setting for this, according to Marcus, was neither politics nor the physical culture movement, but religion. Only religion has the force, he said, 'to open our soul' and to awaken 'a different, second, greater human being'. ${ }^{50}$ Religion for him was 'the beating heart' together with the 'feeling soul' and he called their fusing 'sacred. 51

With regard to the present, Marcus said, precisely the right moment had come to bring such a person to life. 'The new cultural situation', he said, has acquired so much sobriety and new objectivity, that it was virtually predestined to gain experience with the sacred. For this reason, he was now seeking 'the objective person with a warm heart', who could explain how he shaped his life. ${ }^{52}$ He saved the surprise for the end. Where could you meet such a person and bring them to life? In the author's view, the proper place for this would be 'in the sacral experience of the erotic'.53

tion, $403-82$.

47 Wedemeyer-Kolwe, Der neue Mensch, 13-4.

48 Hugo Marcus, 'Die Religion und der Mensch der Zukunft', Moslemische Revue, 2, (1930), 65-74; Moslemische Revue, 3 (1930), 94-8; Moslemische Revue, 1 (1931), 24-31.

49 Marcus, 'Die Religion', 66.

$50 \quad$ Ibid., 68 et passim.

$5^{1}$ Ibid., 69 et passim.

52 Ibid., 74 et passim.

53 Marcus, 'Die Religion', Moslemische Revue, 1 (1931), 97 et passim. We will return to the subject in Chapter 7 . 
His appeal received very different responses. Rolf von Ehrenfels was the first to react. He was a young baron from Austria, a follower of phenomenology, and a rising star in the life reform movement. ${ }^{54}$ Just one year previously he had converted to Islam in the Berlin mosque and was named co-publisher of the Moslemische Revue. Ehrenfels advocated a methodical manner of life. He encouraged simplifying one's lifestyle in all areas of human action; these included gender relations, home furnishings, clothing, nutrition and child raising: it also covered the conscious perception of one's immediate environment and approaching the sacral sphere in a concentrated manner. Ehrenfels did not refute eroticism, but shifted its focus. Praying five times a day, he said, should be the basis of one's life because, more profoundly than eroticism, praying was capable of healing the soul. According to his views, however, it was a simple lifestyle in which the soul could position itself that could best confront modern times. He viewed the objects of Islamic culture as leading the way in this regard.

Ehrenfels was succeeded by Faruq H. Fischer, a young Nazi ideologue whom Marcus introduced to the mosque in 1934 amid much ado. ${ }^{55}$ Fischer saw the solution in hygiene, athletics, bonding with nature and in being subordinate to the nation (Volk). He believed that to renew oneself, you had to feel as if you were part of the whole. You should not smoke or drink alcohol, you should eat vegetarian food and lead a simple life: these were the prescriptions that both life reform and Islam were proposing to the people, but, as Fischer saw it, the 'Führer of the German people' was already doing just that. 'Our leaders are acting in a Muslim sense' was his triumphant conclusion. An individual merging with another person, referred to as eroticism, received no further mention from him.

As a homosexual, Hugo Marcus was probably thinking of men when he drafted his vision. However, the women in the German-Muslim Society also paid attention to his words, for they resonated well with their own ideas. The views of Abdullah's assistant imam, Azeez Ur-Rahman Mirza (1906-37), who

54 Baron Omar R. Ehrenfels, 'Der Islam und die junge Generation in Europa', Moslemische Revue, 3 (1931), 81-91; Baron Omar R. Ehrenfels, 'Islam als Lebensform', Moslemische Revue, 1 (1936), 2-6. Cf. Siv Hackzell, Umar Rolf Ehrenfels: Mother-right Anthropologist of the 'Vienna School' in the Cultural Triangle Europe-India-East Africa (BA thesis at Stockholm University, Department of Social Anthropology, 2011).

55 Fischer was temporarily appointed a board member and made a member of the editorial staff of the Moslemische Revue. Faruq H. Fischer, 'Ist der Islam unmodern?' Moslemische Revue, 2 (1934), 62-74. Behind this Muslim nom de plume was Hans Fischer, the man who was celebrating great acclaim in the Ruhr basin region as the author of anti-Semitic comedies and farces. 
came from the famous Bakhsh family in Lahore, were closer to those of the women. His father Mirza Khuda Bakhsh had been an early follower of Mirza Ghulam Ahmad and had written a concise synopsis of the latter's theological work. ${ }^{56}$ Like Abdullah, he had studied physics and chemistry and learned how to work with abstract probability calculations. Azeez Mirza did not like either the individualism that Marcus's proposal advocated, nor Fischer's appropriation of it. In 1932 he gave two lectures in the mosque in which he succinctly depicted the difference between German members of the life reform (Lebensreform) movement and Indian religious reformers:

The essence of Islam is live and let others live. Let the Darwins of Europe cry out 'survival of the fittest'. It may be true, but the point is, are you going to allow the unfit to die and wither away? ... A child, when he takes his birth, is quite unfit to live an independent life. He is too weak to make his way through the world. Do you then propose to let him alone and let him die? Where Darwin insists on 'the survival chances of those bringing benefit', Islam teaches us something very different. It tells us to serve the weak and prepare them for an independent life. ${ }^{57}$

In his attempt to reject the right of the fittest, which he associated with Europe, Azeez Mirza was only to a limited extent speaking out for the weak. None of his listeners would have objected to his chosen example of a helpless child. By turning to the child, he was expressing veiled criticism of oppressive Nazi policies, yet broaching a subject that appealed to the feelings of the people, especially the women, in the German-Muslim Society. The debate thereby took a totally new turn.

Azeez was also attempting to change the men. The new image of humanity that he had in mind, however, was rooted in a very different tradition. ${ }^{58}$ As he was growing up, there was a debate in Ahmadiyya circles in Lahore on the need to educate women. Women were supposed to study the religious texts and thus be in a position to raise their sons properly. Studying the Quran in depth could also help them support their husbands and, if necessary, correct them. At times, it dealt with a cautious restructuring of gender relations. The image of

$5^{6}$ http://wiki.qern.org/mirza-ghulam-ahmad/biography/followers/mirza-khuda-bakhsh.

57 Private Archive Oettinger, two manuscripts: 'The Spirit of Islam I' (23 August 1933) and 'The Spirit of Islam II' (10 December 1933). Passage cited from 'The Spirit of Islam I', 8-9.

$5^{8}$ The following is based on Avril A. Powell, 'Duties of Ahmadi women: educative processes in the early stages of the Ahmadiyya Movement', in Anthony Copley (ed.) Gurus and their Followers: New Religious Reform Movements in Colonial India (Oxford: Oxford University Press, 2001) 128-59. 


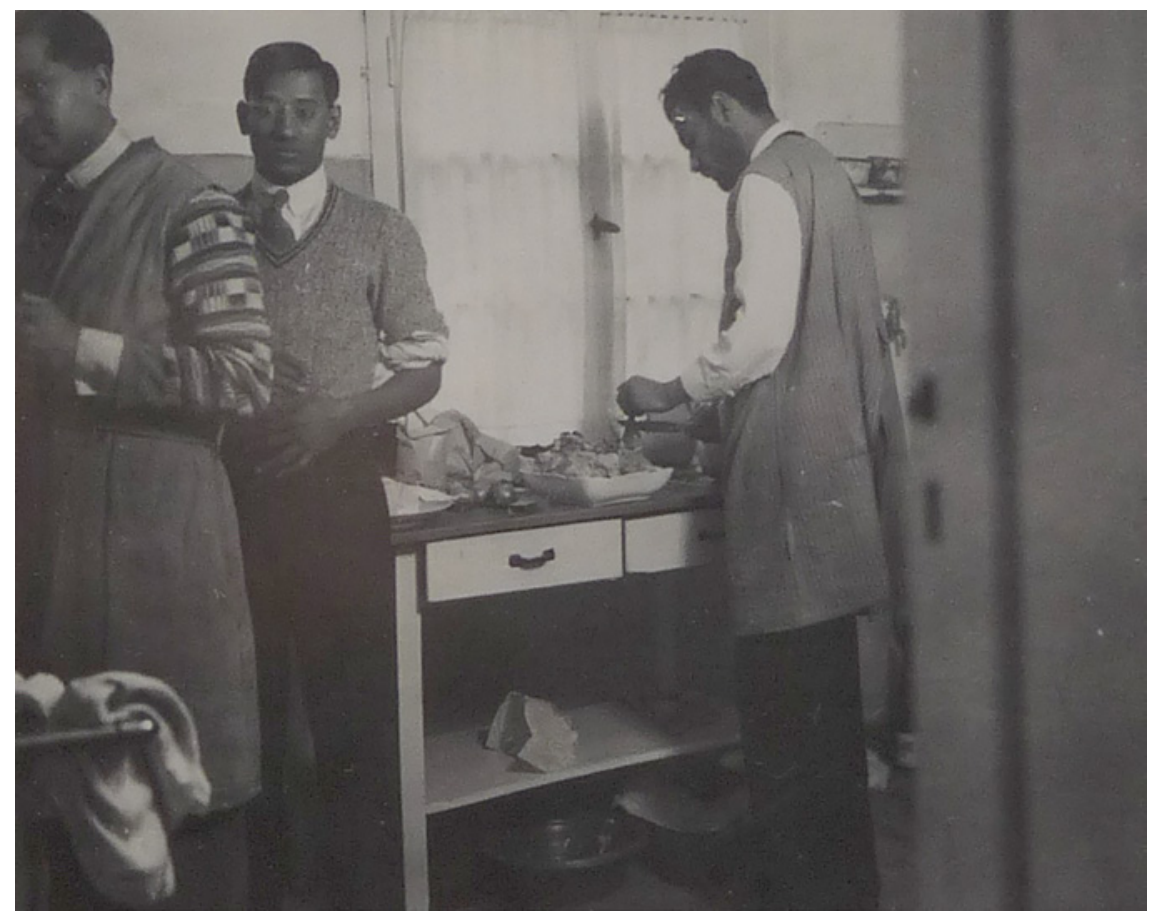

FIGURE 3.4 Young men in the mosque kitchen, Eid al-Fitr 1933

the modern Muslim wife that was thereby drafted closely resembled the Victorian helpmate, thus improving the compatibility of the mission, which the Lahore-Ahmadiyya was at the time preparing.

His attemps to continue this discussion in Berlin arose from the need to address, at least to some extent, the expectations of emancipated women. This was captured in a photograph in the mission house kitchen depicting young Indian men with their sleeves rolled up and wearing aprons. They are earnestly chopping vegetables and stirring pots. Azeez wrote the following on the back: 'GOD HELPS THOSE WHO HELP THEMSELVES. SATURDAY THE 2OTH OF JANUARY AND JUST A DAY AFTER EID AL-FITR 1933. ON OUR WAY TO ENJOY THE EID DAYS. 12 NOON. AZEEZ MIRZA, BERLIN'59 (Figure 3.4.).

Azeez Mirza was not a Quran scholar, but a physicist. The quotation he chose was not from the Quran, but from Benjamin Franklin, the American publisher, scientist, and inventor (1706-90) who not only helped draft the American Declaration of Independence, but also dedicated himself to the struggle to abolish slavery. Azeez meant this seriously, for he sent the young

59 This photograph is also in Emilia Oettinger's collection (Oettinger private archive). 
German-Muslim Society men into the kitchen. He wooed the hearts of German women, particular that of Lisa Oettinger, who certainly noticed. She later became his wife and he gave the photograph to her mother.

The women did not say much, but they did act. They chose Indian partners and the Moslemische Revue helped them inform themselves very accurately about the legal situation in Muslim countries and the Sharia regulations that prevailed there. ${ }^{60}$ An intercultural marriage, including the children it produced, seemed to them to be an innovative cultural mission that the couple had to master together. ${ }^{61}$ As many photographs show, the mosque was a sort of matchmaking centre. For Lisa and Susanna Oettinger, this presented a unique opportunity. In 1932, five years after they first met Abdullah, the two of them each brought home an Indian fiancé. It is worth noting that Hugo Marcus's appeal to create a 'new human being', the so-called New Man, took a very different turn for the women in the German-Muslim Society.

It is telling that Abdullah kept largely out of the debate. Before it ensued he had already written a long text on the status of women in Islam. ${ }^{62}$ In it, he defended the classical Islamic position, which stipulates that the genders complement each other but are equal before God. Then again, he emphasized the role of education, which would turn unknowing women into educated spouses, which could raise a traditional marriage to a higher level. Abdullah's 'New Man' thus involved a cautious modification of gender relations. Once it appeared in printing, every bride and groom was given a copy of his treatise on their wedding day. ${ }^{63}$

In a further step, he invited the Sufi master Hossein Kazemzadeh Iranschär to the mosque to speak about the soul. Kazemzadeh was a fascinating person. ${ }^{64}$ After the First World War, during which he had a revolutionary career,

6 S.M. Abdullah, 'Die Stellung der Frau im Islam', Moslemische Revue, 3 (1929), 113-32; Anon, 'Recht, Einbürgerung und Ehegesetze in Ländern mit islamischer Bevölkerung', Moslemische Revue, 2 (1935), 50-3; Mehmed Begovic, 'Allgemeine Übersicht über die Entwicklung und die Prinzipien der islamischen Ehe', Moslemische Revue, 2 (1934), 74-89; Mehmed Begovic, 'Die Anwendung des Schariarechts in den Balkanstaaten', Moslemische Revue, 2 (1935), 54-6o; Gotthard Jäschke, 'Die Form der Eheschließung nach türkischem Recht', Moslemische Revue, 1 (1940), 35-7; D.M. Kauschansky, 'Hauptelemente des türkischen Eherechts', Moslemische Revue, 1 (1934), 6-13.

61 Latifa A. Roessler, 'Ein Arbeitsfeld für die muslimische Europäerin', Moslemische Revue, 1 (1934), 13-6; Hildegard Scharf, Irma Gohl and Hudah J. Schneider, 'Drei Europäerinnen bekennen sich zum Islam', Moslemische Revue, 1 (1931), 53-9.

62 Abdullah, 'Die Stellung der Frau im Islam'.

63 Private Oettinger archive; private Soliman archive.

64 Jamshid Behnam, 'Iranschär' and 'Iranschär, Hossein Kazemzadah', in Ehsan Yarshater (ed.) Encyclopedia Iranica, vol. 13 (2006), 535-6 and 537-9. 
he settled down as a bookseller in Berlin. Then, in 1925, he underwent a spiritual volte-face and joined both the Theosophical Society and the Inayat Khan Suf Lodge, where he carved out a new career for himself as a charismatic preacher. By 1930, Kazemzadeh was one of the most successful spiritual speakers and writers in Berlin. From the publishing company he headed, it is apparent that he not only edited books on Theosophy and Sufism separately, but also combined them with each other. ${ }^{65}$ His lectures at the mosque would fill the house to the brim and the transcripts of some of his speeches were published in the mission's journal. ${ }^{66}$

According to Islamic tradition, questions about the soul fall into the realm of the Sufi orders, though inferences about it are also drawn from the Quran. Given that in many parts of the Islamic world, the activities of mystics are considered a legitimate supplement and reinforcement of Sharia, it was just a logical step for Abdullah to steer the 'New Man' debate in that direction. With Kazemzadeh's appearance on the scene, the members of the life reform (Lebensreform) movement suddenly confronted the figure of a Muslim mystica doubting, searching, suffering person attempting to kindle the divine spark through exercise and renunciation. For Muslims, this had always been a difficult and strictly regimented endeavour, although Kazemadeh's mixture of Sufism and Theosophy probably made it easier for life reformers to understand the basic ideas of Islamic mysticism. Lisa Oettinger was clearly attracted by his comments because, from the archive she left to her son, it is apparent that he provided fertile ground for the development of her own personal religiosity (Chapter 4).

It was Kazemzadeh who introduced the concept of the Aryan soul into the debate - and with that the lofty notion of 'Aryan' descent, which Indians and Persians, as well as Germans, claimed for themselves. He thus brought in a long series of scholarly lectures and treatments dealing with the essence and the history of Islamic mysticism, the origins of Aryans, and their mutual relations

65 Starting in 1929 Iranschär Verlag published The Aquarian Path: A Monthly Journal Devoted to the Study of Esoteric Philosophy and the Ancient Mysteries. The publisher's programme included works on Persian mysticism, Die Heilkraft des Schweigens (1929), Die Gathas von Zarathustra (1930), and Barg Sabz/Grüne Blätter (1933).

66 Hossein Kazemzadeh Iranschär, 'Wie sollen wir meditieren?' Ahmadiyya Mosque Archive (Berlin, 1932); Hossein Kazemzadeh Iranschär, 'Aus dem Leben eines Sufimeisters des Islam', Moslemische Revue, 3 (1933) 50-9; Hossein Kazemzadeh Iranschär, 'Meine Pilgerfahrt nach Mekka, der heiligen Stadt des Islams', Moslemische Revue, 3 (1935) 75-87; Hossein Kazemzadeh Iranschär, 'Die Seele kennen und Verlangen', Mosque Archive, Berlin (1935); Hossein Kazemzadeh Iranschär, 'Das Mysterium der Seele', Ahmadiyya Mosque Archive, Berlin (1936); Hossein Kazemzadeh Iranschär, 'Die Ursachen des Leidens, Ahmadiyya Mosque Archive, Berlin (1936). See ibid. nos. 17, 26, 34. 
in the East and West. Between Hugo Marcus's soul, which he once wanted to tear open to awaken a 'different, greater human being', and the intercultural melting pot, in which 'Aryans' from East and West came together, lay a long and winding road full of surprises. In addition to the possibility of entering into intercultural marriages, this seems to have been the main attraction of the German-Muslim Society.

The Nazi Party platform of 1920 gave a clear-cut answer to the question of who would be permitted to live in Germany in the future. If it were up to them, from then on only Volksgenossen (members of the German nation), that is, people of 'German blood', would be citizens. ${ }^{67}$ All others would be subject to the legislation pertaining to aliens. The Nazi Party warned non-Germans that it would be best for them to leave the country. On 30 January 1933, Adolf Hitler, the Führer of the National Socialist (Nazi) Party, took power. 'The end came much more rapidly than ever envisaged and with a radicalism that no contemporaries could ever have imagined'.68

The radical changes taking place on the streets of Berlin did not go unobserved by the mosque congregation. Yet, nobody discussed the Storm Detachment (Sturmabteilung) marches, the nightly raids, the brawls on Kurfürstendamm boulevard, the burning of the Reichstag, the public book burnings, or the boycott of Jewish shops, which included shattering their windows and looting their shelves. On the surface, everything remained as it had been. In January, the month of Ramadan began. All the discussions in the Moslemische Revue were about doing without food and the power of perseverance. Only Johanna Hudah Schneider, an older member of the congregation in Zurich around whom the Muslim students there had rallied, wrote an article in the Moslemische Revue of April 1933 that carried any mention of the gloom that surrounded them: 'it seems as if everything is senseless in the face of the gigantic will of a superior power of darkness to annihilate, to destroy the good and elevate the evil' ${ }^{\prime} 9$

67 Diemut Majer, 'Fremdvölkische' im Dritten Reich: Ein Beitrag zur nationalsozialistischen Rechtssetzung und Rechtspraxis in Verwaltung und Justiz unter besonderer Berücksichtigung der eingegliederten Ostgebiete und des Generalgouvernements (Boppard: Harald Boldt Verlag, 1981), 83-4.

68 Karl Schlögel, Das russische Berlin. Ostbahnhof Europas (Munich: Pantheon, 2007), 73.

69 Johanna Hudah Schneider, 'Der Sinn des Leidens: Meditation', Moslemische Revue, 1 (1933), 27-8. In 1931 she also published a conversion report in the Moslemische Revue; 
Directly following the Nazis' assumption of power, the same Hudah Schneider sent Azeez Mirza a series of postcards with urgent requests and questions. ${ }^{70}$ 'How are all of you? I'm very worried. Just a word' (2 February); 'I'm very worried and I am thinking of you in the dreadful chaos. Please stay at home until the 5 March, so that nothing happens to you' (24 February). ${ }^{71}$ Other postcards contained requests for Azeez to check on certain Muslims mentioned by name from whom she had not heard for a while. Hudah Schneider was concerned that, given the daily attacks in the streets on people who looked like Jews, her Muslim friends might be in danger. In fact, as we know from various sources, they were. ${ }^{72}$ Because the German public was sold such a negative picture of 'Orientals', in which Jews and Muslims were indistinguishable (hooked nose, beady eyes and dark skin), migrants from Turkey, India, or Egypt, as well as dark-skinned Jews from Germany, were spat at and insulted on the streets. Consequently, some migrants sought ways to show that they were 'friends' of the German people. The Turkish modiste Rebia Tevfik Basokcu, who as Madame Saadi ran a successful business in Berlin, took advantage of the old German-Turkish 'brotherhood in arms' adage and planted a Turkish flag in the sand whenever she went bathing in the Baltic Sea. ${ }^{73}$

Muslims of Jewish descent experienced the effects of the political upheaval. Hugo Marcus's older brother, Dr Richard Marcus, who was the district commissioner of Leipzig, 'was the first government official in Saxony to be dismissed, spied on and driven to his death. ${ }^{74}$ When the congregation heard the news, the local committee of the Islamic World Congress convened a meeting in the mosque on 15 May 1933 to express their condolences to Marcus and, at the following meeting, he thanked the committee for its thoughtfulness. ${ }^{75}$

Emilia Oettinger and her two daughters were concerned with something else. Susanna had become pregnant from her Indian fiancé who then abandoned her. On 10 June 1933, she gave birth to a child with dark skin who soon developed a full head of strikingly dark curls. The timing was extremely

Scharf et al., 'Drei Europäerinnen', 53-6. In 1937 the journal published her obituary, Moslemische Revue, 1 (1937), 32.

70 Private Oettinger archive, Lisa Oettinger's postcard album.

71 The Reichstag elections took place on 5 March 1933.

72 Höpp, 'Zwischen Universität und Straße'.

73 Rebia Tevfik Basokcu, 'Überlebenskampf und Karriere einer Modistin in den Goldenen Zwanzigern', in Ingeborg Böer, Ruth Haerkötter and Petra Kappert (eds) Türken in Berlin 1871-1945 (Berlin: De Gruyter, 2002), 221.

74 Hugo Marcus private archive, Box 1, autobiographical outline, c.1956.

75 Registry Office Berlin-Charlottenburg, No. VR 9 ER 1.33, report 19 (15 May 1933) and report 20 (29 May 1933). 
unfortunate. Like any Oriental-looking people on the streets, dark-skinned children also faced hostility, were spat at, insulted by neighbours and often expelled from school. ${ }^{76}$ From the moment of her birth, Susanna's child Rani was welcome nowhere. Not only had she been born out of wedlock, but also her dark skin and hair attracted hostile behaviour from which her mother could hardly protect her.

The situation of the Jews in Germany, including those with 'only' one Jewish parent, changed rapidly. ${ }^{77}$ The sisters also felt threatened; although they were raised without a religion and had at most an academic interest in Judaism, they were now branded as Jews. Viktor Klemperer, who was baptized and married to an 'Aryan' woman, was the son of a Reform rabbi. He kept an extensive diary of the changes taking place. He saw a picture of his father in the anniversary issue of the Jewish Reform Community, and wrote that 'in it was ... a history of its efforts on behalf of Germanness. It now appears nothing short of tragic.'78 Although the two sisters were supposed to enjoy a 'special status' because they were of mixed blood (Mischlinge), they were increasingly isolated, harassed, treated as outcasts, and ultimately exploited as forced labourers. Even if the details of the persecution had not yet been determined at that time, in early 1933 the threat was already hanging over them like a dark cloud.

Far away in Lahore, the political upheaval in Germany was not viewed as bleakly as it was by those directly affected. In 1934, Lahore-Ahmadiyya president Muhammad Ali sent his congratulations to the Nazi regime: 'we welcome the new regime in Germany, as it promotes the simple principles of life inculcated by Islam: ${ }^{79}$ Not only the president, but also members of the mosque in Berlin expressed admiration, drawing parallels between Islam as they perceived it and the Nazi regime. The composition of the board of the GermanMuslim Society was changing. At its annual meeting, Emilia Oettinger, the apolitical life reformer, received only three votes. ${ }^{80}$ Consequently, she stepped down, but remained connected to the society as a member. She also continued

76 Eyewitness accounts can be found in Katharina Oguntoye, May Opitz and Dagmar Schultz (eds) Showing Our Colors: Afro-German Women Speak Out (Amherst, MA: University of Massachusetts Press, 1992), 56-76; Gorch Pieken and Cornelia Cruse, Preussisches Liebesglück: Eine deutsche Familie aus Afrika (Berlin: List, 2008), 150, $170 \mathrm{ff}$.

77 Friedländer, Nazi Germany and the Jews, 145-5, 368 fn. 38.

78 Viktor Klemperer, I Will Bear Witness. Part 2: Diaries 1933-1941 (New York: Random House, 1998), 119 (22 April 1935).

79 Moslemische Revue, 1 (1934), 45.

8o Registry Office Berlin-Charlottenburg, VR no. 8769 (11 October 1934). 
to attend the annual members' meeting, accompanied either by Lisa or Susanna. ${ }^{81}$

Society members who were also members of the Nazi Party - Hikmat Beyer, Albert Seiler, Faruq Fischer, Omar Schubert and Amin Boosfeld - collected most of the votes in $1934 .{ }^{82}$ Although a Jew, Hugo Marcus was once again confirmed in his position, ${ }^{83}$ but had to resign the following year due to increased Gestapo pressure on board members. The Nazi dominance on the executive board did not seem to disturb him. When he announced his resignation, he suggested Klopp von Hofe, an SS man, as his successor. ${ }^{84}$ In this way the society adapted to the new conditions. The following year Abdullah reported to the Foreign Office:

Our president Mr Boosfeld is a member of the victims' circle of the NSDAP [Nazi Party]; 85 our second secretary Dr Klopp von Hofe is a member of the NSDAP and the SS; the treasurer Mr Schubert is a member of the Labour Front, and the first assessor Mr Beyer is a member of the NSDAP. ${ }^{86}$

In 1936, 50 Muslims in Berlin who supported the Nazi regime denounced the German-Muslim Society to the Gestapo ${ }^{87}$ and several board members in the society joined them. ${ }^{88}$ The denunciation was part of a concerted worldwide attempt by the media to attack the Ahmadiyya movement. Muslims in Berlin then took this opportunity to try to take control of the mosque, which they considered essential in the power struggle to become the official representative of the Muslim world in Nazi Germany. Their attack therefore targeted Abdullah as the on-site representative. ${ }^{89}$

The conflict, which highlighted the differences between the LahoreAhmadiyya and the other Muslims in Berlin, resulted in heated debates. As was explained in the Introduction, the missionaries were not part of the ulema, the Muslim scholarly elite, but proposed religious reforms on their own initiative

$81 \quad$ Registry Office Berlin-Charlottenburg, VR no. 8769 (21 September 1935; 19 September 1936; 20 September 1937; 8 September 1938).

82 VR no. 8769 (11 October 1934).

83 Ibid.

84 Registry Office Berlin-Charlottenburg, VR no. 8769 (21 September 1935).

85 This refers to the 'Circle of Victims of the NSDAP', It includes early Nazi Party members who received prison sentences in the Weimar Republic.

86 AA PA, 104.801 (31 August 1936).

87 Jonker, The Ahmadiyya Quest, 120-1; Ryad, 'Salafiyya, Ahmadiyya'.

88 Ryad, 'Salafiyya, Ahmadiyya', 90-1.

89 AA PA, 104.801 (1936-1939). 
and as they themselves thought best. Worse, their proposals were based on cosmopolitan ideas and principles of negotiation that were targeted to include Western audiences. The other Muslims hated their lecture evenings, hiking groups, tennis matches and tea parties, which they regarded as un-Islamic. In the battle for the mosque, they spied on Abdullah's private life, secretly photographed him and sensationalized his lifestyle in the Arabic and Urdu daily newspapers with devious reports and suggestive photographs. The petitions that the 50 denouncers signed claimed, among other things, that Abdullah spent time with 'impure' women, played tennis with his wife while other Muslims were praying, and ate and participated in the sale of pork. In addition, they said, he was letting the Berlin mosque degenerate into a tearoom. ${ }^{90}$

Abdullah was fighting for his life. Not only did he feel forced to submit declarations to contradict the slander in two different directions, but he was also having to deal with the division that cut right through his congregation. His innumerable letters to the Foreign Office asserting his innocence were piling up and his Muslim adversaries were taking him to court. ${ }^{91}$ Meanwhile, Azeez Mirza was desperately trying to repair the mosque's damaged image by installing traditional religious structures. One of their resolutions was to introduce 'Muslim evenings' twice a month with a view to 'answering religious questions objectively'. ${ }^{92}$

These were all accusations that got the Muslim readership's adrenalin flowing, but what got the Nazi administration to its feet concerned the Jewish members of the mosque, more precisely the claim that the German-Muslim Society was 'a shelter for criminals, communists, and Jews'. ${ }^{33}$ This accusation led to an in-depth investigation by the Nazi Party that lasted for three years and that targeted not only the mosque but also the survivors of the Inayat Khan Sufi Lodge and a number of Egyptian bars. While the final report denied the presence of criminals and communists, it confirmed that the mosque indeed served as 'a shelter for Kurfürstendamm Jews'. ${ }^{94}$ Although its wording drew attention to the density of the relationships between Muslims and Jews in the district, the investigation was nevertheless discontinued in 1939. With an eye to

9o According to the Lahore daily Zamindar of 5 June 1936 . The photos and texts were sent to the Foreign Office and are located in the file: AA PA, 104.801 (1936).

91 AA PA, 104.801 (Abdullah to Pilger) (31 August 1936).

92 Registry Office Berlin-Charlottenburg, VR no. 8769 (19 September 1936).

93 AA PA, 104.801: Declaration of the 50 signatories to the Gestapo (23 February 1936); investigation report of the Nazi party to the Chief of Police in Berlin (13 April 1937). Not until three years later did the Gestapo issue a final judgment: Gestapo to Reich Minister of the Interior for Church Affairs (11 February 1939). See also Chapter 4. 
the approaching war, nobody in Nazi Berlin wanted to damage relations with any Muslim representatives in the capital. Despite obvious differences between Nazi and Muslim interests, and despite the latter's closeness to the Jews, the Nazi regime saw all Muslims in Berlin as allies and potential allies in the upcoming war. ${ }^{95}$ Until then, it wanted to keep all options open.

Things quietened down in the German-Muslim Society. The lecture and publication series continued, but no new joint initiatives were launched. Instead, the centrifugal forces dominated. Anyone wishing to avoid becoming a suspect in the eyes of politically active Muslims in Berlin moved to the Berlin Islamic Community. All the others withdrew into their private spheres.

Why did the Oettinger women remain in the hornet's nest, especially after the German-Muslim Society had declined? They shared neither religious nor political motives, but only their friendship with the two imams. Their futures were at stake. Lisa had converted to Islam and was engaged to Azeez, the second imam. Susanna was still hoping to find a partner in the mosque and her friends were there. They continued to go hiking in Brandenburg and sunbathing in the mosque garden, and were happy to be part of an international, cosmopolitan society. The Abdullahs and Azeez Mirza had become part of their extended family and seemed to hold the keys to the future in their hands. In 1937, when the worst attacks were over, Lisa and Azeez moved to Lahore. As we shall see in the next chapter, the couple promised to apply for visas as soon as they arrived in Lahore, so that the rest of the family could join them. However, because of the dramatic developments that took place on their arrival, that plan never came to fruition and waiting for them was to no avail. When the war started in the autumn of 1939, the Abdullahs delayed their departure in the hope that the documents might still arrive to allow both families to embark on the passage together. In the end, they travelled alone to Lahore, while Emilia, Susanna, and Rani remained behind, waiting with their bags packed.

Motadel, Islam and Nazi Germany's War, 38-71. 